\title{
Investigating Morphological Process of Payandra on Javanese Metaphor
}

\author{
Dwi Astuti Wahyu Nurhayati \\ Institut Agama Islam Negeri Tulungagung, Indonesia \\ dwiastuti_76@yahoo.co.id;dwiastuti507@gmail.com
}

\begin{abstract}
This article examines morphological process on payandra used by pranata adiacara. This study was done through a survey to pranata adiacara in Trenggalek and Tulungagung surroundings, small districts in East Java-Indonesia, in order to get underlying basis of processes of morphological on Javanese style which are influential toward their language style used in Javanese marriage ceremonies. The instrument- interview \& documentation were developed in accordance to get the morphological processes and panyandra used by pranata adiacara. The study reveals that payandra and processes of morphological on Javanese style used by pranata adiacara are divided into including 2 two main types: 1) Affixation (a. Internal change, $b$. Prefixation ; 2) Non Affixation: $a$. Compounding, $b$. Borrowing, $c$. Blending, $d$. Backformation, e. Reduplication, $f$. Clipping and the words used by pranata adiacara in sentences. Finally, the results of this study offers language phenomena arises because of some reasons which are mainly useful for those conducting communication among pranata adiacara and the audiences to figure out how beautiful and handsome of the bridge and bridegroom and the values of wishes in conducting traditional ceremonies and those who are concerned in investigating panyandra words and metaphors used by pranata adiacara or other varieties as well as suggestions for future research.
\end{abstract}

Keywords: Panyandra, Morphological process, Javanese, metaphor

JELTL, Vol. 1 (3), 2016 


\section{INTRODUCTION}

Living in the modern era should not cause people forget their own culture but globalization influences all aspects of people's life, especially the community of South east Asia including Indonesia. The effect of globalization era also arise less appreciation of Indonesian generation to their own language, culture, especially Javanese, Javanese is one of language of dialects which is used as the first language when they communicate with their parents at informal situation. Language is used to create a meaningful communication among human beings. Communication is impossible without shared knowledge and assumption between speakers and hearers (Stubbs in Nurhayati et.al, 2016e).

The second one is they also forget about Javanese culture. Most of them could not speak Javanese (High speech level; Krama Inggil). They prefer to listen and consume western nuanced products. In fact, many of them have forgotten their indigenous cultures. Most of them have adopted western culture such as dressing styles, having sex before married and less appreciating the older people or norms.

Even though most young Indonesian generation cannot speak Javanese language and forget Javanese culture, but some parts of Javanese communities including Yogyakarta, Surabaya, and Jakarta, or outside of Java areas still preserve the Javanese culture. The adherence to the Java community rites is not displaced traditional Javanese bride. The descendants of Javanese who live in those cities feel the higher prestige when the marriage ceremony is conducted using Javanese tradition. They will feel prouder if the wedding ceremonies are performed using Javanese tradition

Actually, it becomes a national education problem. As teachers, it is better to preserve Javanese culture by introducing Javanese style which is used in Javanese wedding ceremonies. The Javanese style which used by adiacara is more wellknown as panyandra. Thus it is a challenging to explore panyandra usually used in wedding ceremonies in which Indonesian generation would be willing to learn and appreciate more Javanese culture. Panyandra as one of Javanese metaphor is important to know for most of young generation. Panyandra as one style and structure related to ethics and politeness in Javannese community in the semiotics perspective, ethics, and language (Errington in Nurhayati, 2014c). Hoover (2016) also investigated metaphors as collocation is important to study especially to understand more abstract concept in terms of concrete ones. Creating or using metaphor as sociological fashion, for example network as metaphor plays as prominent role in contemporary social science (Erickson, 2012). Metaphor and metonymy in word formation is conducted using semantic side of proportional analogy in the formation of instrumentals and agent nouns especially in compounding (Basilio, 2006) unfortunately the discussion of metaphor is relative disregard to word-formation process, not focuses on certain dialect. It is the main reason to conduct this research. It is useful for young generation especially students to know their own dialect what panyandra is and how panyandra words are formed, used in sentences analyzing through morphological process. It is expected that this study can increase the students or the readers' Javanese culture and metaphors. 


\section{LITERATURE REVIEW}

Nyandra, the roomates is comparing two things, based on resemblance or similarity, without using "like" or "as", is used in Javanese society to illustrate something so particular as to the make that thing look more alive. One example is how to express the beauty of a human's body. All of the words that used in panyandra are basa krama inggil.

Panyandra are beautiful words that are pronounced by panatacara, as an expression of an idea of the atmosphere that is being told about the face. Those words are used delivered to all the people who listen as viewers or guests. It is usually used to describe the beauty of the place, beauty, handsomeness, and the beauty of the state, the picture conveyed through the greeting words beautifully composed using high Javanese literature, right metaphors, and gives the original parable to something more beautiful than that is going on, all of which meant that the state is being told appropriate and the same can be described with the actual state of beauty. This is closely-related to the way Javanese society views politeness, in which expressing one's feelings directly is considered to be taboo. Such a condition has created a certain type of tradition i.e. nyandra where flowery words 'basa rinengga' in the form of metaphors are used.

The Javanese ceremonial events require a guide for the implementation of a series of events can take well and completely. The guide is often called the MC (master of ceremonies) is usually translated as adicara. A more precise translation, $\mathrm{MC}$ is pranata laksitaning adicara, pranata adicara because he make the atmosphere in the ceremony become sacred and commotion so as not to seem empty and deserted.

Pranata adicara is only person who believed to assemble a series of events in traditional Javanese wedding procession. As the "messengers" in addition to serving the disordering of the atmosphere, while diving drinking water, do not feel that the pranata adicara has been instrumental take part in perpetuation language, literature, and culture of Java. In the wedding ceremony, pranata adicara deliver all of his words in Javanese. Not only common language, but also he use special language that used by pranata adicara or pranatacara. This language is called Panyandra (Suwarna, 1998).

Panyandra is classified as metaphor used in Javanese ceremonies especially wedding ceremonies. Panjandrum in this study can be said as language in use, including metaphor always occurs in a specific context, where it is produced and made sense of by specified people (Cameron, 2003. P.13). Metaphor in panjandrum can be used in the explanation of key concepts and learning strategies, and may sometimes become a shared reference for teacher and pupils. This can be seen as attractor in interactional talking and thinking.

Learning the metaphors in panyandra can be focused on the metaphorical conceptual frameworks structuring knowledge and rationality, and how people operate with them is a good potential source for different kinds of learning (Berent, 2008, p.14). It is highlighted the practical relevance using metaphorical networks in L3 context of teaching Javanese and English morphological processes. 
Morphological process is the process in which the language user combines one morpheme with another in order to form a word or a process of combining two morphemes in finding new word. Two main types of morphological process includes: (1) affixation; (2) non affixation (Yule, 1996, p. 63-70; Nurhayati, 2015a.p.60-62). This study only focuses on the morphological processes which arise in wedding ceremonies used by adiacara or pranata acara including (1) Affixation (internal change means that complete change of form; prefixes means using prefix to form a new word; (2) Non Affixation: (a) Compounding is combining two words resulting new meaning; (b) Blending: Mixing, usually we combine the initial letter/combining two separate forms to reproduce a single term. Typically this is accomplished by taking only the beginning of one word and joining it to the end of other word such as brunch is derived from breakfast and lunch, motel $=$ motor + hotel, bionic, infotainment, transistor; (c). Borrowing means that language has not term in the language itself or it can be said that one of the most common source s of new words in English is process simply labeled borrowing, that is taking over of words from other languages; (d) backformation is the formation of a word from one that looks like its derivative. It is usually derived from verbs. Ex: teller from tell, reaper from reap, writer form write, singer from sing, emotion from emote, editor from edit, There is form adjective into nouns: greed from greedy ; (e) Clipping means to cut/to clip the initial part of the word comes gather the final part. Example: final part $=$ ad- advertisement, photo-photograph, the beginning phonetelephone, both: flu-influenza; (f) Reduplication means It is a process of reduplicating either partial (partial reduplication) or entire (total reduplication) grammatical unity, Partial Reduplication can be difference of the initial consonant between the two elements, e.g. walkie-talkie, or medial, e.g. criss-cross. Total Reduplication in English occurs only sporadically and it usually indicates intensity, e.g. goody-goody ('affectedly good'), din-din ('dinner').

Many studies reveal that media or activities are quite effective for teaching English skills or other linguistics knowledge, Nurhayati's study (2008a) indicates the frequency of conducting various activities could make the students more enjoyable to study English especially reducing their burden to join activities. Moreover, the update research of using interesting media to inspire reading comprehension conducted Nurhayati (2014b) investigated retelling the ideas and summarizing text using interesting picture series could increase the students 'motivation in reading class, and Nurhayati's study (2015b) also investigated using creative games or activities also could improve the students' English pronunciation ability.

It is also supported by Nurhayati's study (20115a, 2016b) investigated morphological and morphophonemic process of Alay variation and revealed that morphological process including affixation: internal change, infixation and core vowel; non affixation e.g. borrowing, coinage, clipping, acronym, multiple process, reduplication and combination text; and the morphophonemic process of allay variation related to loss of phoneme, addition of phoneme, simple consonant change; process of word formation and technique understanding slang words used by waria Tulungagung are divided into 11 (eleven) processes including derivation, multiple 
process, acronym, Borrowing, Blending, Reduplication, Synonym, Coinage, Irregular Form, Echoism, Changing of Syllable Vowel and the technique of understanding Waria sentences by removing some suffixes, other Nurhayati's study (2016c) investigated phonological system of Tengger dialect, revealed that the use of consonants and vowels for different lexicon, as one of Javanese dialect which has almost the same system of vowel and consonant but have different slightly in syllabic and cluster construction and it constantly survives because the users of Tengger dialect would like to keep maintaining it as the ancestors' heritage.

It is also supported by Nurhayati's study (2016d) investigated that using a dialect is a part of speaking and it is defined as a process of using verbal an nonverbal symbols in any context (local drama). Then it is important to conduct this study in order to dig up more about Javanese dialect, style or metaphor in order that young generation know better their own dialect and culture's values used in panyandra words.

\section{RESEARCH METHOD}

This study which is aimed at describing at panyandra used by pranata acara and on what kinds of morphological process were constructed by pranata acara or adi acara in Tulungagung and Trenggalek through conducting observation and an interview toward pranata acara, Tulungagung and Trenggalek, East Java, Indonesia. The respondents ranging from the 18 up to 60 year pranata acara were randomly selected.

The instruments used to get the data in this study are interview and observation. Ary et.al (2010:430) state that "observation is the most basic method for obtaining data in qualitative research. The most common method of recording the data collected during observation is field notes". The data were taken when the pranata acara performed in wedding parties. The first meeting, pranata acara got performed to conduct the wedding ceremonies, the researcher observes how they communicate each other by recording and taking notes all their utterances. There were several performances of being pranata adiacara in wedding parties. Instead of observing and taking field notes, there were also several meetings pranata adiacara in informal situation such as in their houses. During the observation, all panyandra words were recorded and taken notes. They (2010:434) further mention that interview is used to gather data on subjects' opinion, belief and feelings about the situation in their own words. Interviews provide information that cannot be obtained through observation. It was conducted informal interview with informants in some days, the purpose is to know the language they used in informal situation, define the meaning of the words contextually and describe the processes of word formation. The pranata adiacaras' utterances used in various activities are analyzed by using descriptive qualitative research. According to Ary,et al (2010:442), content or document analysis is a research method applied to written or visual materials for the purposes of identifying specified characteristics. 


\section{FINDINGS AND DISCUSSION}

The findings of this study show that some morphological processes are used in panyandra including two main types: 1) Affixation (a. Internal change, b. Prefixation; 2) Non Affixation: a. Compounding, b.Borrowing, c. Blending, d. Backformation, e. Reduplication, f. Clipping.

\subsection{Affixation}

The first main type in morphological process of panyandra is affixation. It has two sub types processes including internal change and prefixes.

\subsubsection{Internal change}

It means that the internal vowel's changing in those words are followed by suffix-en/, for example in this table below.

Table 1. Internal Change process of Panyandra Words

\begin{tabular}{|l|l|l|}
\hline Process & Word & Meaning \\
\hline Gawa + an & gawan & something that someone brings \\
\hline Tuku + an & tukon & something that someone bought \\
\hline Lali + an & Lalen & A forgetful man \\
\hline Bantu + en & bantunen & please help him! \\
\hline Swara + ing & swaraning & the voice of something \\
\hline Jodho + ake & jodhokake & get a match \\
\hline$n+$ tulis & nulis & write \\
\hline
\end{tabular}

Based on the table above, it can be said that the internal change of those words is added the suffixes /-an,-en,-ake/ and the prefix /-n/, and

\subsubsection{Prefixation}

Preffixation is used to create some panyandra words especially related to adverb of frequency, noun, adjective and profession.

Table 2. Preffixation Process of Panjandrum Words

\begin{tabular}{|c|c|c|c|}
\hline Prefix & Meaning & Example & Meaning of the word \\
\hline \multirow[t]{4}{*}{ Sa- } & \multirow{4}{*}{ In the same, one } & sadinten & In a day \\
\hline & & saminggu & In a week \\
\hline & & Sanggriya & In the same home \\
\hline & & sabungkul & Intact \\
\hline \multirow[t]{3}{*}{ Pi- } & \multirow{3}{*}{$\begin{array}{c}\text { Action that } \\
\text { done by other } \\
\text { people }\end{array}$} & pitutur & Opinion \\
\hline & & piwulang & Teaching \\
\hline & & pikantuk & Get \\
\hline \multirow[t]{2}{*}{ Ka- } & \multirow[t]{2}{*}{ Have done } & kawaca & Have been read \\
\hline & & kasembah & honourable \\
\hline \multirow[t]{2}{*}{-ne } & owner & wimbane & Her/his eyebrow \\
\hline & & rikmane & Her/his hair \\
\hline
\end{tabular}

Based on the table above, it can be said that the process of preffixation needs using some prefixes such as /sa- as sadinten means a day, prefix/-pi/ in -(pitutur means 
advicel, prefix /-ka/ kawaca mean it is read (verb3), the root rikma+the suffix/-ne/ rikmane (as noun hair).

\subsection{Non- affixation}

Non-affixation which is used to create panyandra has 6 (six) processes as follows:

\subsubsection{Compounding}

\subsubsection{Solid Compound}

Solid compound means combining two words in order to create new words as certain terms.

Table 3. Solid Compounding process of Panyandra words

\begin{tabular}{|l|l|l|}
\hline No & Solid Comp & Meaning \\
\hline 1 & Nagasari & name of Javanese traditional food \\
\hline 2 & Rajawredi & blue sky \\
\hline 3 & Banyuwangi & name of city \\
\hline 4 & Surabaya & name of city \\
\hline
\end{tabular}

It creates compounding words related to the name of traditional food, the terms of blue sky, the names of cities.

\subsubsection{Hypenated Compounding}

It hypenates two word which arise new meaning.

Table 4. Hypenated Compounding process of Panyandra words

\begin{tabular}{|l|l|l|}
\hline No & Hyp Comp & Meaning \\
\hline 1 & Randha-royal & fried cassava with wheat flour packing \\
\hline 2 & Sawo-mateng & brown color skin (Javanese skin) \\
\hline
\end{tabular}

It creates some compounding words related to a snack (it represents as if the name of a widow) and personal appearance of Javanese people.

\subsubsection{Regular Compounding}

Regular compounding means combining two words and arising or creating new meaning related activities, condition, adjective, noun.

Table 5. Regular Compounding process of panyandra words

\begin{tabular}{|l|l|l|l|}
\hline No & word & process & Meaning \\
\hline 1 & Paripurna & Pari + purna & has finished \\
\hline 2 & Paring Piwucal & Paring + piwucal & teach \\
\hline 3 & Marak Sowan & Marak + Sowan & visit parents \\
\hline 4 & Randa tanggung & Randa + tanggung & young widow \\
\hline 5 & Lara ati & Lara + ati & hatred \\
\hline 6 & Asor budine & Asor + budi & ala budine $:$ bad attitude \\
\hline 7 & Dhuwur & Dhuwur + pangkate & sugih panguasane ( VIP) \\
\hline 8 & Jembar kawruhe & Jembar + kawruhe & clever \\
\hline 9 & Padhang langite & Padhang + langite & look happy \\
\hline 10 & Panas atine & Panas + atine & nesu/ angry \\
\hline
\end{tabular}


The regular compounding words relate to adjective (people characters, condition, verbal activities, and position of authority)

\subsubsection{Borrowing}

Borrowing is the second process in creating panyandra words. It means to borrow some words from other languages such as Arabic and Malay as the words in this table below.

Table 6. Borrowing process of Panyandra words

\begin{tabular}{|l|l|l|l|}
\hline No & Word & Language & Meaning \\
\hline 1 & Waris : waris & Arabic & Heritage \\
\hline 2 & Tamu : tamu & Malay & Guest \\
\hline 3 & Adat : adat & Arabic & Norm \\
\hline 4 & Budaya: budaya & Malay & culture \\
\hline
\end{tabular}

Those borrowing word are derived from or borrowed some term of other languages such as Arabic and Malay.

\subsubsection{Blending}

The third process is blending process. It means to blend two words into one word as the new creation word in this table below.

Table 7. Blending process of Panyandra words

\begin{tabular}{|l|l|l|l|}
\hline No & Word & Process of blending & Meaning \\
\hline 1 & aneng & /ana + ing / & exist \\
\hline 3 & dupyarsa & /dupi+arsa/ & efforts \\
\hline 4 & jiwangga & /jiwa + angga/ & Knight soul \\
\hline 5 & lumakweng & /lumaku+ing/ & The man \\
\hline 6 & miring & /mara + ing/ & suddenly \\
\hline 7 & narpati & /nara + pati/ & tilt \\
\hline 8 & prowirotama & /prawita + utama/ & Close to the death \\
\hline 9 & rajendra & /raja + endra/ & The best soldier \\
\hline 10 & sarotama & /sara + utama/ & dynasty \\
\hline 11 & tumekeng & /tumeka + ing/ & The main things \\
\hline 12 & wirotama & /wira + utama/ & arrival \\
\hline 13 & yeku & /ya + iku/ & bravery \\
\hline 14 & sitinggil & /siti + inggil/ & e.g. \\
\hline 15 & jalwestri & /jalu+estri/ & highland \\
\hline 17 & kapyarsa & /kapireng + arsa/ & couple \\
\hline 18 & murbeng & /murba + ing/ & To tell something \\
\hline 19 & malbeng & /malebu+ing/ & The almighty \\
\hline 20 & narpendah & /narpa + endah/ & Enter into \\
\hline 21 & panggung & /panggon+manggung/ & stage \\
\hline 22 & prabawa & /para + legawa/ & wise \\
\hline 23 & wasana & /wawas + wekasan/ & After that \\
\hline
\end{tabular}




\begin{tabular}{|l|l|l|l|}
\hline 24 & wimbuh & /wiwit+imbuh/ & confused \\
\hline 25 & sarju & /sarta+setuju/ & agree \\
\hline 26 & pranah & /para + manah/ & heart \\
\hline 27 & legawa & /lega+lelewa/ & patient \\
\hline 28 & keket & /ketok+raket/ & very tight/close \\
\hline 29 & karoban & /karo+keleben/ & Fish story (rumor) \\
\hline 30 & mawa & /manggon+nggawa/ & with \\
\hline 31 & Sinom & /si+enom/ & young people \\
\hline 32 & Kalongkerat & kaloka + ing + rat & famous \\
\hline 34 & Murdantaji & murda + kita + aji & worth \\
\hline 36 & Saking & saka + ing & from \\
\hline 37 & Munggeng & munggah + ing & up to \\
\hline 38 & Sarwendah & sarwa + endah & always beautiful \\
\hline
\end{tabular}

The blending process creates some new words by blending two words and creating new words and terms. Those words usually are created to enlarge or enhance the various of Javanese words or style to beautify the expressions.

\subsubsection{Backformation}

The fourth process is backformation. It means that these new words are derived from the root as wirya, wibawa, sandang and others.

Table 8. Backformation process of payandra words

\begin{tabular}{|l|l|l|}
\hline No & Word & Process of backformation \\
\hline 1 & Kawiryan & It is derived from wirya \\
\hline 2 & Kahartan & It is derived from harta \\
\hline 3 & Kawibawan & It is derived from wibawa \\
\hline 4 & Nyenyandhang & It is derived from sandhang \\
\hline 5 & Pangertosan & It is derived from ngertos \\
\hline 6 & kasmaran & It is derived from asmara \\
\hline 7 & Ngrasaaken & It is derived from rasa \\
\hline 8 & kongkonan & It is derived from kongkon \\
\hline 9 & Mangarsa & It is derived from kerso \\
\hline 10 & Kaparengan & It is derived from pareng \\
\hline 11 & Hangambara & It is derived from hangambar \\
\hline 12 & nyenyandhang & It is derived from nyandhang \\
\hline 13 & Kalingga & It is derived from lingga \\
\hline 14 & hamestuti & It is derived from astuti \\
\hline
\end{tabular}

(Demang, 2013)

Based on the table above it can be said that all those words got backformation process, those words are derived from the roots with the prefixes / ka-wirya and suffix-n, prefix/ ka/ + harta+ suffix $\mathrm{n} /$ as kahartan, the prefix /nyel $+n y$ (infix)+sandang, prefix /pal + ngertos+ suffix -an in pangartosan(understanding), prefix /ng/+ rasa+ suffix/aken/ in ngrasaaken (felt), root/kongkon/ + suffix/an/ in kongkonan, the prefix /ma/+kerso becomes mangarsa, the prefix/ka/+pareng+ 
suffix-/an/ becomes kaparengan, the root hangambar+sufix /a/ becomes hangambara(very famous; fragant), the prefix /nyel+ nyandang becomes nyenyandhang (wearing a dress), prefix / ka/+lingga / becomes kalingga (bird), the prefix ham+astuti becomes hamestuti (do the task).

\subsubsection{Reduplication}

The fifth process is reduplication. It reduplicates as partial and total words.

\subsubsection{Partial Reduplication}

The first reduplication is partial reduplication which reduplicate only a part of the word. It can be the vowel in the middle of those words.

Table 9. Partial reduplication process of panyandra words

\begin{tabular}{|l|l|l|}
\hline No & Word & Meaning \\
\hline 1 & gonjang-ganjing & A very crucial condition \\
\hline 2 & mesam-mesem & smiling \\
\hline 3 & lenggak-lenggok & Have a walk calmly \\
\hline 4 & digawe-gawe & pretended \\
\hline 5 & sir-sir an & go steady or have a girl friend \\
\hline 6 & korat-karit & A messy condition \\
\hline 7 & jujur-ajur & Being honest causes worse condition \\
\hline 8 & mawantu-wantu & Very much \\
\hline 9 & gonyak-ganyuk & Often do mistakes \\
\hline 10 & Hangemba-embaning & vague \\
\hline 11 & $\begin{array}{l}\text { Andhoyong- } \\
\text { ndhoyongan }\end{array}$ & Push each other \\
\hline 12 & Panganyam-anyaming & Hopes or wishes \\
\hline 13 & Hamiwir-miwir & Stroked her hair \\
\hline 14 & Kaanti-anti & It is waited \\
\hline 15 & Amemba-embaning & As if \\
\hline 16 & Rum-rinungrum & $\begin{array}{l}\text { Help each other (do not priority the } \\
\text { material) }\end{array}$ \\
\hline 17 & Sih-sinihan & $\begin{array}{l}\text { Berkasih-kasihan (make love: the one } \\
\text { she/he misses) }\end{array}$ \\
\hline 18 & Hatampel-tampel & Very closely \\
\hline 19 & Jenjem-jinem & Very silent \\
\hline 20 & Puja-puji & praise \\
\hline 21 & Pinudhi-pundi & Very good \\
\hline 22 & Ambyor-mopyor & Get united \\
\hline 23 & Ginatha-gantha & as if \\
\hline 24 & Salami-lami & forever \\
\hline 25 & Lon-lonan & walk together \\
\hline 27 & Ayak-ayakan & Hand bone \\
\hline 28 & Widadara widadari & angels \\
\hline & & \\
\hline 26 avanese Music instrument \\
\hline $19 n$
\end{tabular}




\begin{tabular}{|l|l|l|}
\hline 29 & Hapsara hapsari & Beautiful (dayang: princes' guardian) \\
\hline 30 & Dewa dewi & God \&goddes \\
\hline 31 & Putra putri & Boys \&girls \\
\hline 32 & Bathara bathari & God \&goddess \\
\hline 33 & Raseksa raseksi & giants \\
\hline 34 & Mudha mudhi & youngsters \\
\hline
\end{tabular}

(Kusnadi,2000).

Partial reduplication is the various type of adiacara or pranata acara used to figure out the bridesmaid and bridegroom 'appearance, condition, activities during the wedding ceremony and also best wishes using panyandra words.

\subsubsection{Total Reduplication}

The second reduplication is total reduplication which uses reduplicate those word to create panyandra words in wedding ceremonies. It can be seen the examples in this table below.

Table 10. Total Reduplication of Panyandra Words

\begin{tabular}{|l|l|l|}
\hline No & Total Reduplication & Meaning \\
\hline 1 & Blalak-blalak & Big eyes \\
\hline 2 & Kelap-kelap & shiny \\
\hline 3 & Unen-unen & says \\
\hline 4 & Bocah-bocah & children \\
\hline 5 & Kapang-kapang & Many times \\
\hline 6 & Kados-kados & As if \\
\hline 7 & Mugi-mugi & The best wish \\
\hline 8 & Werno-werno & various \\
\hline 9 & Langkung-langkung & furthermore \\
\hline 10 & Tuladha-tulada & examples \\
\hline 11 & Bab-bab & matters \\
\hline 12 & Lamat-lamat & slowly \\
\hline 13 & Kakeen-kakeen & grandfather \\
\hline 14 & Ninen-ninen & grandmother \\
\hline 15 & Daya-daya & power \\
\hline 16 & Gita-gita & sooner \\
\hline 17 & Sigra-sigra & ready \\
\hline 18 & Jaya-jaya & wisdom \\
\hline 19 & Rempyoh-rempyoh & burden \\
\hline 20 & Ayu-ayu & beautiful \\
\hline 21 & Kaya-kaya & As if \\
\hline 22 & Gebyar-gebyar & shiny \\
\hline 23 & Runtung-runtung & together \\
\hline 24 & Alang-alang & grasses \\
\hline 25 & Nedheng-nedheng & Can't bear \\
\hline 26 & Wage-wage & The name of birthrate \\
\hline 27 & Dhampyak-dhampyak & In hurry \\
\hline & & \\
\hline
\end{tabular}




\begin{tabular}{|l|l|l|}
\hline 28 & Lengkeh-lengkeh & Slim waists \\
\hline 29 & Nini-nini & women \\
\hline
\end{tabular}

(Mangunsuwito, 2010)

The total reduplication is a process used by pranata adi acara to figure out all the conditions or activities in wedding ceremonies as symbols words (styles). It definitely needs good understanding of panyandra words to know what the adiacara conveys.

\subsubsection{Clipping}

The sixth process is clipping. It clips the final part of the word which can be seen in this table below.

Table 11. Clipping Process of Panyandra Words

\begin{tabular}{|l|l|l|l|}
\hline No & Clipping & Javanese & English Meaning \\
\hline 1 & $\mathrm{Ji}$ & $($ siji $)$ & one \\
\hline 2 & Ro & $($ loro $)$ & two \\
\hline 3 & Lu & $($ telu $)$ & three \\
\hline 4 & Pat & $($ papat $)$ & four \\
\hline 5 & Ma & $($ lima $)$ & five \\
\hline 6 & Nem & $($ enem $)$ & six \\
\hline 7 & Tu & $($ pitu $)$ & seven \\
\hline 8 & Lu & $($ wolu $)$ & eight \\
\hline 9 & Nga & $($ sanga $)$ & nine \\
\hline 10 & Luh & $($ sepuluh $)$ & ten \\
\hline 11 & Nika & $($ punika $)$ & that / those \\
\hline 12 & Napa & $($ punapa $)$ & what \\
\hline 13 & Teng & $($ dhateng $)$ & in \\
\hline
\end{tabular}

Clipping process is also used to create Panyandra words to make all those Javanese various words becomes more unique and beautiful.

All those six morphological processes represent how those panyandra words are derived from or combined by using some phases.

\subsection{Panyandra Words are Used by in Wedding Ceremonies Sentences}

The first sentence used by pranatacara is as follows, "Dhasar sulistya ing warna tan kinira yen ta mustikaning pawiwahan Rara Silvia. Denira lumampah alelewa kaemba sardula lapa, lembehane mbalarak sempal...." It means that Rara Silvia (bridesmaid) is really beautiful, it amazed everyone. She is walking like a hungry tiger, her hands movement is like coconut trees (blarak sempal)"

The second sentence is as follows, "Lejar penggalihe, aningali eseme panganten putri saking katebihan jengkar saking palenggahan, jumeneng nambut kanthi hangantu-antu pangeranipun. Byar sumunar pasuryaning temanten putri amirsani temanten kakung. "The bridegroom becomes calm (his mind), he smiles when he sees the bridesmaid which he sat in far and stands from his seat, welcome 
the bridesmaid with many hopes. The bridesmaid's face shines when she sees the bridegroom.

\subsection{Panyandra's Words}

4.4.1 Panyandra words are used to express the beauty of a woman

Table 12. Panyandra Words of Appreciating woman's beauty

\begin{tabular}{|l|l|l|}
\hline No & Panyandra & Meaning \\
\hline 1 & Rikmane & her hair \\
\hline 2 & Angembang & Dense \\
\hline 3 & Bakung & like a bakung's plant \\
\hline 4 & Micis & Smooth \\
\hline 5 & Wutah & like a coin that fall \\
\hline 6 & Wimbane & her eyebrow \\
\hline 7 & Nanggal sapisan & like moon in the first date \\
\hline 8 & Kadya & like \\
\hline 9 & Liyep & closed eyes \\
\hline 10 & Lindri & slow \\
\hline 11 & Tumeng & faced one \\
\hline 12 & Tawang & sky \\
\hline 13 & Ngudup mlati & sharp nose \\
\hline 14 & Kencana & gold \\
\hline 15 & Pinastika & high quality \\
\hline 16 & Sumunar & has something that interest \\
\hline
\end{tabular}

4,4,2 Panyandra Words are Used to Express the Handsome Man

Table 13. Panyandra Words of Appreciating Man's bravery

\begin{tabular}{|l|l|l|}
\hline No & Panyandra & English Meaning \\
\hline 1 & Jatmika & Respectful \\
\hline 2 & Sarira & Body \\
\hline 3 & Prabata & like a mountain ( big, strong) \\
\hline 4 & Ngoling & Angry \\
\hline 5 & Simbar & hairy chested \\
\hline 6 & Riyak & As if \\
\hline
\end{tabular}

(Pravita, 2015)

Those two tables are used to figure out or appreciate the beauty of bridesmaid and the bravery, handsome and wise bridegroom. Both of them are a couple as a beautiful queen and a handsome king who are ready to face a new life or phase.

\section{CONCLUSION}

In the Javanese wedding ceremony, Panyandra plays as an important role, the preserving of traditional Javanese wedding ceremony is very dependent on pranatas'skills especially how create and combine any processing words during the ceremony procession, as in traditional wedding Javanese ceremony. All the words 
which are used in ceremonies as symbols and movement symbols or it can be said as figurative language as metaphor or style. To know all those words (panjandrum), it needs to translate into literary words.

During the wedding ceremonies, pranata acara conveys panyandra as higher speech level (Krama inggil). By knowing and understanding panyandra, it is expected to give linguistic knowledge especially style, metaphor and understand good manners of Javanese language, understand the meaning of style or metaphor. It also can provide an overview and imagery appropriate to the circumstances, so there is no confusion to understand the pranata acara's ideas about the processing of Javanese wedding ceremonies.

Panyandra can be produced and analyzed using the morphological process. Every process can be understood and improve the student' knowledge about how the words derived from or created.

\section{REFERENCES}

Ary, D., Jacobs.C. L., Sorensen, C., \& Razavieh, A. (2010). Introduction to Research in Education (8thEds). Canada: Wadsworth Canage Learning Nelson, Ltd.

Berent, A. E. (2008). Metaphors for Learning: Cross-cultural Perspectives. Philadelphia: John Benjamins Publishing Company.

Basilio, M. (2006). Meatphor and Metonymy in word Formation. DELTA Journal.Vol.22

Cameron, L. (2003). Metaphor in Educational Discourse. London: MGP Books Ltd.

Demang, K. S. (2013). Upacara Pengantin Adat Jawa. (Online), (http://kidemangsodron78.wordpress.com/panyandra/ html), retrieved June 16, 2013.

Erickson, M. (2012). Network as Metaphor. International Journal of Criminology and Sociological Theory. Vol. 5.No. 2. August.912-921. (online). http://dx.doi.org/10.1590/S0102-44502006000300006.

Hoover, L. D. (2016). Metaphors we may not live by. Literary-Linguistics International Journal. 2016 Vol.5.No.1.2016.1-16.

Kusnadi, E. (2000). Permadani' Ringkesan Basa lan Sastra Jawi. Yogyakarta : Kanisius.

Mangunsuwito, S.A. (2010). Kamus Lengkap Bahasa Jawa. Bandung : Yrama Widya.

Nurhayati, Dwi Astuti Wahyu. (2008a). Improving Students English Vocabulary Mastery through Games (A Classroom Action Research in the Islam Kindergarten of Al-Irsyad Madiun in the Academic Year 2007/2008). Surakarta. Graduate School of Sebelas Maret University.

Nurhayati, Dwi Astuti Wahyu. (2014b). Using Picture Series to Inspire Reading Comprehension for the Second Semester Students of English Department of IAIN Tulungagung. Dinamika Ilmu Journal. Vo.14.No.2.December 2014.176189. 
Nurhayati, Dwi Astuti Wahyu (2014c). Kesantunan Pragmatik dalam Bahasa Guru bahasa Inggris di sekolah dasar Islam. Proceedings of the $1^{\text {st }}$ PRASASTI 2014 (Pragmatik: Sastra dan Linguistik).(I), 27 November 2014.52-60.http: //dx.doi.org/10.20961/pras.v0i0.

Nurhayati, Dwi Astuti Wahyu. (2015a). Morphological Process and Morphophonemic Process of Alay Variation. Lingua.Vol.12.No.1,March 2015: pp.59-70.

Nurhayati, Dwi Astuti Wahyu. (2015b). Improving Strudents'English Pronunciation Ability through Go Fish Game and Maze Game. Dinamika Ilmu Journal. Vol. 15.No.2,December 2016: pp. 215-234.

Nurhayati, Dwi Astuti Wahyu. (2016b). Word Formation Processes and a Technique in Understanding Waria Slang Tulungagung. EFL Journal. Vol.1.No.1 March.2016.57-87.

Nurhayati, Dwi Astuti Wahyu. (2016c). Phonological System of Tengger Dialect in Ngoko Speech Level. Indonesian Journal of EFL and Linguistics Vol 1. No. 1.March. 2016.1-12.

Nurhayati, Dwi Astuti Wahyu. (2016d). Using Local Drama in Writing and Speaking: EFL Learners' Creative Expression. JELTL. Vol.1.No.1.April 2016.51-57.

Nurhayati, D.A.W, Djatmika, Riyadi,S.,Wiratno,T.(2016e). Indoneisan Influence in Developing Speaking Skill in Learning English : EFL Learners'Impediments. Proceedings of the Third International Seminar PRASASTI, (III, 2-3 August 2016.67-96. http://dx.doi.org/10.20961/pras.v0i0.

Pravita, D. (2015). Tuladha Panyandra Penganten Jawa. (online), (http://dianpravita.com/tuladha-panyandra-penganten-jawa), retrieved 15 April 2015.

Puschman, C \& Burgess, J. (2014). Metaphors of Big Data. International Journal of Comminication Vo.8. 1690-1709.

Suwarna. (1998). Gita Wicara Jawi Pranatacara saha Pamedharsabda. Yogyakarta: Kanisius.

Yule, George. (1996). The Study of Language. New York: Cambridge University Press. 